\title{
Morphometric analysis of basal cell layer in oral premalignant white lesions and squamous cell carcinoma
}

\author{
A H M SHABANA, N G EL-LABBAN, K W LEE \\ From the Institute of Dental Surgery and Eastman Dental Hospital
}

SUMMARY The size and shape of the cells in the basal cell layer of the oral epithelium in 100 specimens from oral mucosa were studied by using an interactive image analysis system (IBAS-1). Four groups of white lesions (traumatic keratosis, lichen planus, leucoplakia, and a "risk group") in addition to two control groups (normal mucosa and squamous cell carcinoma) were studied retrospectively. The results showed a progressive increase in the dimensions (area, perimeter, and maximum diameter) of the nuclei from normal mucosa through traumatic keratosis, lichen planus, leucoplakia and the "risk group" to carcinoma, with considerable differences. The nucleus in squamous cell carcinoma was twice as large as in normal mucosa. A substantial increase in the dimensions of both the cell and the nucleus was found in the "risk group." The nucleo:cytoplasmic ratio, contrary to what might have been anticipated in risk lesions, did not show considerable differences between the diagnostic groups. Furthermore, it was slightly decreased in the risk group compared with the normal mucosa. The shape factors (form PE and contour index) seemed to be less helpful in the identification of the "risk group." The size of the basal cell and its nucleus can be of diagnostic value for lesions with a high risk of malignant transformation.

Oral squamous cell carcinoma may be preceded by premalignant lesions. The most common of these lesions is leucoplakia which is defined as a white patch that cannot be attributed to any other disease. ${ }^{1}$ The rate of malignant change in leucoplakia ranges between 3 and $6 \% .^{2}$ This rate may be higher in particular variants of leucoplakia-for instance, candidal leucoplakia has been reported to show $30 \%$ malignant change. ${ }^{3}$ Oral lichen planus carries little or no risk of malignant transformation, although it is suggested that the atrophic or erosive form may. The reported rates of malignant transformation in patients with oral lichen planus range between 0 and $2 \% .^{45}$

In the examination of oral mucosal lesions that may be premalignant histopathologists have problems not only in differentiating between various lesions but also in determining the risk of malignant change in the individual case. The histopathological diagnosis of oral premalignant lesions is based on the subjective evaluation of epithelial dysplasia, but

Accepted for publication 10 September 1986 the wide variation between observers in the subjective evaluation of epithelial dysplasia has been commented on by several authors ${ }^{6-8}$ and more objective means of evaluation are constantly sought for.

In the assessment of dysplastic and neoplastic lesions, a great emphasis is placed on the changes in nuclear and cellular size and shape. To overcome the unreliability in the subjective examination of these features a more objective approach would be the value of computer based image analysis techniques.

The keratinocytes of the basal cell layer of the oral stratified squamous epithelium represent the progenitor cells that are responsible for the production of other cells making up the various layers of the epithelium. Changes in the basal cells may have serious implications on future cell behaviour, including malignant transformation. The measurement of their size and shape in white lesions may be an important prognostic marker.

\section{Material and methods}

A retrospective study was made on 100 specimens taken from the buccal mucosa of 97 patients. The 
specimens were selected from the records in the department of oral pathology at this hospital. These comprised 10 specimens of normal mucosa, 14 of traumatic keratosis or frictional keratosis, 20 of lichen planus, 29 leucoplakias (including nine candidal leucoplakias), 16 squamous cell carcinomas, and 11 white lesions which were classified as the "risk group." The diagnosis of the lesions was made by two of the authors (KWL and AHMS) using the World Health Organisation criteria. ${ }^{1}$ Candidal leucoplakia was diagnosed according to the criteria of Cawson and Binnie. ${ }^{3}$ The risk group comprised eight patients with oral squamous cell carcinoma who either had white lesions that underwent malignant change or who had lesions coexisting with carcinomas at first examination. Eleven biopsy specimens were taken, nine being from sites other than those of the carcinomas; one was taken from the site that underwent malignant change and the other was taken from the buccal mucosa adjacent to the carcinoma. The diagnosis was leucoplakia in five, lichen planus in one, and in the five other specimens the appearances were intermediate between lichen planus and leucoplakia. Table 1 shows the age and sex of the patients in each group.

The follow up for the patients ranged between one and 23 years (mean 5.3) for the group with leucoplakia, one and 12 years (mean 4.9) for the group with lichen planus, and one and five years (mean 2.7) for the cases in the risk group with lesions preceding the appearance of cancer. The follow up was not recorded for the other groups. In the group with carcinoma lesions showing a cell layer equivalent to the basal cell layer of the stratified squamous epithelium were selected. Accordingly, these were well and moderately differentiated tumours; only one specimen in this group was poorly differentiated. All specimens were fixed in $10 \%$ formol saline and $5 \mu \mathrm{m}$ thick paraffin sections were cut and stained with haematoxylin and eosin.

Table 1 Diagnostic groups age and sex of patients studied

\begin{tabular}{|c|c|c|c|c|c|}
\hline \multirow[b]{2}{*}{ Diagnostic group } & \multirow{2}{*}{$\begin{array}{l}\text { No of } \\
\text { patients* }\end{array}$} & \multicolumn{2}{|c|}{ Age } & \multicolumn{2}{|c|}{ Sex } \\
\hline & & Range & Mean & $M$ & $F$ \\
\hline $\begin{array}{l}\text { Normal mucosa } \\
\text { Traumatic }\end{array}$ & $10(10)$ & $40-67$ & $(49 \cdot 6)$ & 5 & 5 \\
\hline $\begin{array}{l}\text { keratosis } \\
\text { Lichen planus } \\
\text { Leucoplakia } \\
\text { Candidal }\end{array}$ & $\begin{array}{l}14(14) \\
20(20) \\
20(20)\end{array}$ & $\begin{array}{l}36-73 \\
30-78 \\
33-75\end{array}$ & $\begin{array}{l}(50 \cdot 7) \\
(51 \cdot 8) \\
(52 \cdot 4)\end{array}$ & $\begin{array}{r}6 \\
10 \\
10\end{array}$ & $\begin{array}{r}8 \\
10 \\
10\end{array}$ \\
\hline $\begin{array}{l}\text { leucoplakia } \\
\text { Risk group }\end{array}$ & $\begin{array}{l}9(9) \\
8 \text { (11) }\end{array}$ & $\begin{array}{l}31-80 \\
27-71\end{array}$ & $\begin{array}{l}(53.4] \\
(58.9)\end{array}$ & $\begin{array}{l}6 \\
6\end{array}$ & $\begin{array}{l}3 \\
2\end{array}$ \\
\hline $\begin{array}{l}\text { Squamous cell } \\
\text { carcinoma }\end{array}$ & $16(16)$ & $36-79$ & $(63 \cdot 7)$ & 6 & 10 \\
\hline
\end{tabular}

*No of specimens in parentheses.
MORPHOMETRIC TECHNIQUE

The measurements were made by using a semiautomatic image analysis system (IBAS-1, Kontron). The system comprised a microcomputer, a digitiser tablet, a drawing pen (stylus), a video-camera (CCTV, Hitachi) attached to a light microscope (Olympus $\mathrm{BH}-2)$, and a dot matrix printer (OKI, DP-125). The measurements were made by tracing the outlines of the cells and nuclei displayed on a black and white monitor by the stylus on the digitiser tablet. The contrast of the image was enhanced by a green filter. An oil immersion objective at a magnification of 100 was used to provide the largest possible magnification so that human error in tracing was minimised. The final magnification was 2000 at the monitor.

For each specimen, one section or more that was most representative of the diagnosis was selected. In the lesional areas normal looking tissue was identified and masked by using a black ink marker. The basal keratinocytes were then measured for the parameters described below, except in squamous cell carcinomas where only the nuclei were measured. Histologically identifiable non-keratinocytes such as melanocytes and inflammatory cells, as well as cells showing degenerative changes, those undergoing mitoses, and multinucleated cells, were not measured.

\section{MORPHOMETRIC PARAMETERS}

The sizes of the cells and nuclei were represented by their area, perimeter, and maximum diameter. The shape was measured by "form PE" which assesses the deviation from circularity. By the relations shown in table 2, a circle has a value of 1 and an ellipse or an irregular structure is less than 1. These parameters are part of the videoplan measuring program $(x, y)$. Another shape measuring variable is the Contour Index (CI), which measures the regularity of the particle surface. ${ }^{9}$ A value of 3.54 is obtained for a circle by the formula presented in table 2 . Higher values are obtained with the increase in the indentations or convolutions of the outline. The contour index and the nucleo:cytoplasmic ratio were calculated from mean values.

Table 2 Morphometric parameters

\begin{tabular}{ll}
\hline Parameter & Unit and formula \\
\hline Nuclear area & $\mu \mathrm{m}^{2}$ \\
Nuclear perimeter & $\mu \mathrm{m}$ \\
Nuclear diameter & $\mu \mathrm{m}$ \\
Nuclear form PE & $4 \times 22 / 7 \times \mathrm{N}$ Area $/ \mathrm{N}$ Perim ${ }^{2}$ \\
Nuclear contour index & $\mathrm{N}$ Perim $/ \sqrt{\mathrm{N} \text { Area }}$ \\
Cellular area & $\mu \mathrm{m}^{2}$ \\
Cellular perimeter & $\mu \mathrm{m}$ \\
Cellular diameter & $\mu \mathrm{m}$ \\
Cellular form PE & $4 \times 22 / 7 \times \mathrm{C}$ Area $/ \mathrm{C}$ Perim ${ }^{2}$ \\
Cellular contour index & $\mathrm{C}$ Perim $/ \sqrt{\mathrm{C} \text { Area }} \mathrm{N}$ Area $)$ \\
Nucleo: cytoplasmic ratio & $\mathrm{N}$ Area $/(\mathrm{C}$ Area-N \\
\hline
\end{tabular}




\section{SAMPLE SIZE}

The number of cells to be measured from each specimen was determined by the cumulative mean plot $^{10}$ and was carried out on six specimens representing the various diagnostic groups. The nearest eight cells and their nuclei to the centre of the monitor from each of 25 fields were selected by moving the microscopic stage to the side while the section was out of focus (to avoid selectivity in sampling and to avoid possible image distortion at the edges of the screen). Several sections were used where the length of the epithelium was less than $5 \mathrm{~mm}$. Using this method, 120 cells and nuclei obtained from 15 fields were found to provide a representative sample size for the various parameters in each specimen. The results were then represented by the mean and standard deviation. No corrections for section thickness or the Holmes effect were applied, so that the measurements represent the morphological image as seen.

\section{STATISTICAL ANALYSIS}

The non-parametric Mann-Whitney test was used to evaluate the difference between the distributions of two groups. The Kruskal-Wallis test was used for more than two group comparisons. These rank sum tests were used as the data were often asymmetrical and the standard deviations were also different. A significance level of $5 \%$ was used. The difference between group means divided by the pooled standard deviation is given the value (d). The variables with high (d) values discriminate best between groups. ${ }^{11}$

\section{Results}

Table 3 shows the results of measuring the basal cells and their nuclei in the diagnostic groups. The results showed that the nuclear area, perimeter, and maximum diameter increased steadily from the normal epithelium through traumatic keratosis, lichen planus, leucoplakia, candidal leucoplakia and the risk group to their highest values in squamous cell carcinoma. The nuclear area of the neoplastic cells was about twice as large as that of the normal cells.

The mean values of the whole cell showed similar trends to those of the nucleus. The cell area, perimeter, and maximum diameter of lichen planus lesions, however, were greater, on average, than those in leucoplakia. Nevertheless, the risk group had the largest cell dimensions.

The nucleo:cytoplasmic ratio of the basal cells did not show significant differences between the diagnostic groups. It was noticed, however, that the nucleo:cytoplasmic ratio was slightly lower in the risk group than in the normal group, the opposite of what might have been anticipated in the risk lesions. This decrease in nucleo:cytoplasmic ratio was attributed to the enlargement of the cell to 1.71 times the normal value, whereas the increase in the nuclear area was 1.68 times. In contrast, the increase in nucleo:cytoplasmic ratio in the group with candidal leucoplakia was mainly attributable to the enlargement of the nucleus to 1.46 times. The corresponding increase in the cell area was only 1.38 times.

The group with carcinoma shows the largest nuclear dimensions of all. The shape of the nuclei was more circular than that found in the other groups with the exception of traumatic keratosis which showed the highest value for the nuclear form PE. The contour index of the nuclei showed that candidal leucoplakia had the most irregular shape and the normal group the most regular. All shape factors did not show increasing or decreasing patterns through the groups in accordance with their premalignant potentialities.

Table 4 shows the variables which had (d) values greater than 1, when comparing the risk group with the other groups of white lesions. All the variables listed in the table showed significant differences. The dimensional variables of both the cell and its nucleus seemed to be important for distinguishing the risk

Table 3 Morphometric parameters of basal cell in different diagnostic groups (Mean $\pm S D)$

\begin{tabular}{|c|c|c|c|c|c|c|c|c|c|c|c|c|c|c|c|}
\hline \multirow{2}{*}{$\begin{array}{l}\text { Variable } \\
\text { N Area } \\
\text { N Perim } \\
\text { N Dmax } \\
\text { N PE } \\
\text { N CI }\end{array}$} & \multicolumn{2}{|c|}{$\begin{array}{l}\text { Normal } \\
(n=10)\end{array}$} & \multicolumn{2}{|c|}{$\begin{array}{l}\text { Traumatic } \\
\text { keratosis } \\
(n=14)\end{array}$} & \multicolumn{2}{|c|}{$\begin{array}{l}\text { Lichen planus } \\
(n=20)\end{array}$} & \multicolumn{2}{|c|}{$\begin{array}{l}\text { Leucoplakia } \\
(n=20)\end{array}$} & \multicolumn{2}{|c|}{$\begin{array}{l}\text { Candidal } \\
\text { leucoplakia } \\
(n=9)\end{array}$} & \multicolumn{2}{|c|}{$\begin{array}{l}\text { Risk group } \\
(n=I I)\end{array}$} & \multicolumn{2}{|c|}{$\begin{array}{l}\text { Carcinoma } \\
(n=16)\end{array}$} & \multirow{2}{*}{ 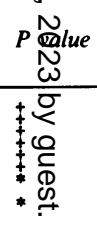 } \\
\hline & $\begin{array}{c}25.01 \\
19.73 \\
7.17 \\
0.780 \\
3.593\end{array}$ & $\begin{array}{l}(3.41) \\
(1.43) \\
(0.73) \\
(0.026) \\
(0.089)\end{array}$ & $\begin{array}{c}29.59 \\
21.32 \\
7.41 \\
0.804 \\
3.944\end{array}$ & $\begin{array}{l}(5.70) \\
(1.78) \\
(0.32) \\
(0.038) \\
(0.130)\end{array}$ & $\begin{array}{c}33 \cdot 10 \\
23 \cdot 12 \\
8 \cdot 27 \\
0 \cdot 781 \\
4 \cdot 029\end{array}$ & $\begin{array}{l}(3.81) \\
(1.17) \\
(0.47) \\
(0.028) \\
(0.128)\end{array}$ & $\begin{array}{l}33 \cdot 13 \\
23 \cdot 18 \\
8 \cdot 33 \\
0.767 \\
4.035\end{array}$ & $\begin{array}{l}(3.30) \\
(1 \cdot 13) \\
(0.67) \\
(0.046) \\
(0.148)\end{array}$ & $\begin{array}{c}36.40 \\
24.37 \\
8.91 \\
0.754 \\
4.051\end{array}$ & $\begin{array}{l}(5.38) \\
(1.65) \\
(0.57) \\
(0.018) \\
(0.067)\end{array}$ & $\begin{array}{c}42 \cdot 06 \\
25 \cdot 81 \\
9.36 \\
0.768 \\
4.013\end{array}$ & $\begin{array}{l}(8.97) \\
(2.39) \\
(0.78) \\
(0.055) \\
(0.168)\end{array}$ & $\begin{array}{c}54 \cdot 34 \\
28 \cdot 64 \\
10 \cdot 28 \\
0.799 \\
3 \cdot 907\end{array}$ & $\begin{array}{c}(10.80) \\
(2.46) \\
(0.90) \\
(0.042) \\
(0.109)\end{array}$ & \\
\hline $\begin{array}{l}\text { C Area } \\
\text { C Perim } \\
\text { C Dmax } \\
\text { C PE } \\
\text { C CI }\end{array}$ & $\begin{array}{c}57.63 \\
31.72 \\
11.00 \\
0.703 \\
4.185\end{array}$ & $\begin{array}{l}(8 \cdot 84) \\
(2.96) \\
(1 \cdot 22) \\
(0.034) \\
(0.120)\end{array}$ & $\begin{array}{c}66 \cdot 78 \\
34.03 \\
11.94 \\
0.720 \\
4 \cdot 182\end{array}$ & $\begin{array}{c}(11 \cdot 10) \\
(2.94) \\
(0.86) \\
(0.046) \\
(0.198)\end{array}$ & $\begin{array}{c}81 \cdot 36 \\
39.62 \\
13.73 \\
0.666 \\
4.401\end{array}$ & $\begin{array}{l}(9.82) \\
(2.57) \\
(1.04) \\
(0.037) \\
(0.155)\end{array}$ & $\begin{array}{c}76 \cdot 13 \\
37.98 \\
13 \cdot 56 \\
0.672 \\
4 \cdot 355\end{array}$ & $\begin{array}{l}(9.45) \\
(3.64) \\
(1.54) \\
(0.057) \\
(0.209)\end{array}$ & $\begin{array}{c}79 \cdot 63 \\
39 \cdot 14 \\
14 \cdot 19 \\
0.652 \\
4 \cdot 392\end{array}$ & $\begin{array}{l}(7.67) \\
(1.84) \\
(0.74) \\
(0.028) \\
(0.111)\end{array}$ & $\begin{array}{l}98 \cdot 28 \\
43 \cdot 73 \\
15 \cdot 39 \\
0.645 \\
4 \cdot 430\end{array}$ & $\begin{array}{l}(16.29) \\
(3.81) \\
(1.15) \\
(0.053) \\
(0.214)\end{array}$ & $\begin{array}{l}\text { ND } \\
\text { ND } \\
\text { ND } \\
\text { ND } \\
\text { ND }\end{array}$ & & $\begin{array}{l} \pm 0 \\
\pm \frac{0}{0} \\
\pm \frac{1}{D} \\
\pm \frac{\Omega}{D} \\
+\frac{0}{Q}\end{array}$ \\
\hline N/Cyt & 0.784 & $(0.151)$ & 0.808 & $(0.156)$ & 0.692 & $(0.080)$ & 0.809 & $(0.215)$ & 0.845 & $(0 \cdot 117)$ & 0.753 & $(0 \cdot 151)$ & ND & i & $-\sigma$ \\
\hline
\end{tabular}

$*=p<0.05 ; \dagger=p<0.01 ; \ddagger=p<0.001$. 
Table 4 (d) values and significance value of different diagnostic groups compared with those of risk group

\begin{tabular}{|c|c|c|c|c|c|c|c|c|}
\hline \multirow[b]{2}{*}{$\begin{array}{l}\text { N Area } \\
\text { N Perim } \\
\text { N Dmax } \\
\text { C Area } \\
\text { C Perim } \\
\text { C Dmax } \\
\text { C PE }\end{array}$} & \multicolumn{2}{|c|}{$\begin{array}{l}\text { Traumatic keratosis } \\
\text { (d) } \\
\quad(\mathrm{n}=14)\end{array}$} & \multicolumn{2}{|c|}{$\begin{array}{l}\text { Lichen planus } \\
\text { (d) } \\
(\mathrm{n}=20)\end{array}$} & \multicolumn{2}{|c|}{$\begin{array}{l}\text { Leucoplakia } \\
\text { (d) } \\
\quad(\mathrm{n}=20)\end{array}$} & \multicolumn{2}{|c|}{$\begin{array}{l}\text { Candidal leucoplakia } \\
\text { (d) } \\
(\mathrm{n}=9)\end{array}$} \\
\hline & $\begin{array}{l}1.31 \\
1.48 \\
1.72 \\
1.52 \\
1.64 \\
1.72 \\
1.23\end{array}$ & $\begin{array}{l}0.001 \\
0.001 \\
0.001 \\
0.001 \\
0.001 \\
0.001 \\
0.05\end{array}$ & $\begin{array}{l}1 \cdot 21 \\
1 \cdot 27 \\
1 \cdot 37 \\
1 \cdot 15 \\
1 \cdot 14 \\
1 \cdot 24\end{array}$ & $\begin{array}{l}0.01 \\
0.01 \\
0.001 \\
0.01 \\
0.01 \\
0.001\end{array}$ & $\begin{array}{l}1.23 \\
1.26 \\
1.19 \\
1.37 \\
1.25 \\
1 \cdot 11\end{array}$ & $\begin{array}{l}0.01 \\
0.01 \\
0.01 \\
0.001 \\
0.01 \\
0.01\end{array}$ & $\begin{array}{l}1.20 \\
1.23 \\
1.08\end{array}$ & $\begin{array}{l}0.01 \\
0.001 \\
0.05\end{array}$ \\
\hline
\end{tabular}

group from the other groups of white lesions. The dimensions of the nucleus, however, were less important in the comparison with those in candidal leucoplakia. The shape factor PE was only valuable for distinguishing the risk group from that with traumatic keratosis.

\section{Discussion}

The present results have shown, that there is a steady increase in the basal cellular and nuclear dimensions from normal mucosa through white lesions, which are generally regarded as reactive (traumatic keratosis), those regarded as chronic inflammatory with little or no risk of malignant transformation (lichen planus), and lesions generally regarded as premalignant (leucoplakia), to the lesions having a high risk of malignant change. The nuclei were also the largest in the group with carcinoma. The (d) values of these indicate that the dimensional features of the basal cells are more important diagnostically than the shape features. The nuclear area was greater than $40 \mu \mathrm{m}^{2}$ in three $(10 \%)$ of the 29 specimens of leucoplakia, in nine $(82 \%)$ of the 11 risk specimens, and in $15(94 \%)$ of the 16 carcinomas. None of the normal, traumatic keratosis, or lichen planus cases had a similarly large nuclear area. Although none of the patients with candidal leucoplakia developed carcinoma during the follow up, the three leucoplakia cases with nuclear area greater than $40 \mu \mathrm{m}^{2}$ were all candidal, representing $33 \%$ of the nine cases of candidal leucoplakia. Cawson and Binnie ${ }^{3}$ reported a $30 \%$ malignant change in candidal leucoplakia.

The present results seem to be compatible with those reported by Boysen and Reith ${ }^{12}$ for the basal cell of the nasal mucosa of nickel workers. Their results showed a progressive increase in basal cellular and nuclear area from pseudostratified columnar epithelium, through metaplastic epithelium, to their highest values in dysplastic epithelium.

The increase in nuclear area in the risk lesions and carcinomas in this study may be a reflection of the increase in DNA synthesis. ${ }^{13} \mathrm{~A}$ proportional increase in the nuclear volume and DNA content was found in the epithelial cells in the mucosa of the uterine cervix.
This study showed that there is a progressive increase from the normal mucosa, carcinoma in situ, to invasive carcinoma. ${ }^{14}$ In oral leucoplakias an increase in the proportion of cells in the hyperdiploid to the hypertetraploid range has been reported. ${ }^{15}$

One of the main causative factors for the increase in the epithelial cell size seems to be mechanical trauma. Such a change has been reported after repeated friction, ${ }^{16}$ in healing wounds, ${ }^{1718}$ after removal of the stratum corneum by Scotch tape stripping, ${ }^{19}$ and after hair plucking. ${ }^{20}$ Similar changes have been described in epithelia during the menstrual cycle, ${ }^{21}$ after applications of turpentine, ${ }^{223}$ and chemical carcinogens. ${ }^{24}$ In a quantitative study of the oral epithelium subjected to friction MacKenzie and Miles found an increase in the total epithelial thickness. ${ }^{16}$ This increase was found in both the size and number of the cells-mainly in the stratum spinosum and stratum granulosum rather than the basal cells. It has been suggested that the epithelial responses to a wide range of stimuli may appear similar but that the various cell compartments may contribute in response with varying degrees. ${ }^{25}$ In quantitative studies on the hamster cheek pouch epithelium after the application of carcinogens Eveson and MacDonald showed progressive increase in the thickness of the progenitor cell compartment. ${ }^{2526}$ This was due to an increase both in size and number of progenitor cells. The authors found that in a control group (scratch or acetone treated animals) there was no change in the mean cell area of the progenitor or maturational cells compared with those in the untreated group. Although the number of progenitor cells increased in the group treated with carcinogens, the striking feature was the highly significant increase in the size of the progenitor cells expressed by the mean cell area. The maturational cells showed a smaller increase in cell size compared with those in the untreated group. The above study emphasised the potential diagnostic and prognostic value of the cell area in the deeper layers of the epithelium. The changes occurring in the basal cells might indicate an increased metabolic activity prior to the invasion of the underlying connective tissues, as shown ultrastructurally. ${ }^{2728}$

Previous studies on the assessment of epithelial 
changes in premalignant lesions from the uterine cervix, ${ }^{29}$ bronchi, ${ }^{30}$ and hamster cheek pouch ${ }^{24}$ have attributed particular importance to the increase in nucleo:cytoplasmic ratio. In the nasal mucosa of nickel workers, however, the increase in the basal cell area resulted in a decrease in the nucleo:cytoplasmic ratio in the dysplastic epithelium. ${ }^{28}$ Our results showed a decrease in nucleo:cytoplasmic ratio of the oral basal cells in the risk group compared with that in the group with leucoplakia, though the difference was not significant.

These results have shown that quantitative techniques can detect features that may be overlooked by routine histological examination. The size of the basal cells and nuclei are not features of epithelial dysplasia. The increase in basal cellular and nuclear size has been shown to be associated with lesions having a high risk of malignant change, and, therefore, their measurement may provide an objective means for the assessment of epithelial dysplasia.

We thank emeritus Professor IRH Kramer (department of oral pathology, Institue of Dental Surgery and Eastman Dental Hospital), Mr C Sowter and Professor G Slavin (department of histopathology, St Bartholomew's Hospital, London) for their valuable comments and suggestions on the methodology.

\section{References}

1 WHO. Collaborating centre for oral precancerous lesions. Definition of leucoplakia and related lesions. Oral Surg 1978;46:518-38.

2 Pindborg JJ. Oral cancer and precancer. Bristol: J Wright, 1980.

3 Cawson RA, Binnie WH. Candida leucoplakia and carcinoma: a possible relationship. In: Mackenzie IC, Dabelsteen E, Squier CA, Eds. Oral premalignancy. Iowa: University of Iowa Press, 1980:59-66.

4 Murti PR, Daftary DK, Bhonsle RB, Gupta PC, Mehta FS, Pindborg JJ. Malignant potential of oral lichen planus: observations in 722 patients from India. J Oral Pathol 1986;15:71-7.

5 Silverman S Jr, Gorski M, Lozada-Nur F. A prospective followup study of 570 patients with oral lichen planus: persistence, remission and malignant association. Oral Surg 1985;60:30-4.

6 Kramer IRH, Lucas RB, El-Labban NG, Lister L. A computeraided study on the tissue changes in oral keratoses and lichen planus, and an analysis of case groupings by subjective and objective criteria. Br J Cancer 1970;24:407-26.

7 Pindborg JJ, Reibel J, Homstrup P. Subjectivity in evaluating oral epithelial dysplasia, carcinoma in-situ and initial carcinoma. $J$ Oral Pathol 1985;14:698-708.

8 Axell T, Holmstrup P, Kramer IRH, Pindborg JJ, Shear M. International seminar on oral leukoplakia and associated lesions related to tobacco habits. Community Dent Oral Epidemiol 1984;12:145-54.

9 Schrek R. Ultrastructure of blood lymphocytes from chronic lymphocytic and lymphosarcoma cell leukemia. JNCI 1972;48:51-64.

10 Chalkley HW. Method for quantitative morphologic analysis of tissues. JNCI 1943;4:47-53.

11 Jagoe R, Sowter C, Slavin G. Shape and texture analysis of liver cell nuclei in hepatomas by computer-aided microscopy. J Clin Pathol 1984;37:755-62.

12 Boysen M, Reith A. A morphometric model for light microscopic analysis of metaplastic, dysplastic and carcinomatous alterations of the nasal mucosa in nickel workers. Pathol Res Pract 1980;166:362-71.

13 Bohm N, Sandritter W. DNA in human tumours: A cytophotometric study. Curr Top Pathol 1975;60:151-219.

14 Valeri V, Cruz AR, Branelao HJS, Lison L. Relationship between cell nuclear volume and deoxyribonucleic acid of cells of normal epithelium, of carcinoma in-situ and of invasive carcinoma of the uterine cervix. Acta Cytol 1967;11:488-96.

15 Saku T, Sato E. Prediction of malignant change in oral precancerous lesions by DNA cytofluorometry. J Oral Pathol 1983;12:90-102.

16 MacKenzie IC, Miles AEW. The effect of chronic frictional stimulation on hamster cheek pouch epithelium. Arch Oral Biol 1973; 18:1341-9.

17 Potten CS, Allen TD. The fine structure and cell kinetics of mouse epidermis after wounding. J Cell Sci 1975;17:413-47.

18 Andersen $L$. Quantitative analysis of epithelial changes during wound healing in palatal mucosa of guinea pigs. Cell Tissue Res 1978;193:231-46.

19 Pinkus H. Examination of the epidermis by the strip method. Biometric data on regeneration of the human epidermis. $J$ Invest Dermatol 1952;19:431-47.

20 Chase HB, Montagna W, Malone JD. Changes in the skin in relation to the hair growth cycle. Anat Rec 1953;116:75-81.

21 Boon ME, Rietveld WJ. Time of ovulation reflected in nuclear and cytoplasmic size of vaginal and buccal epithelial cells. $\mathrm{Ob}$ stet Gynecol 1980;8:778-9.

22 Tarin D. Further electron microscopic studies on the mechanism of carcinogenesis: the specificity of changes in carcinogentreated mouse skin. Int $J$ Cancer 1968;3:734-42.

23 Craig GT, Franklin CD. The effect of turpentine on hamster cheek pouch mucosa: a model of epithelial hyperplasia and hyperkeratosis. J Oral Pathol 1977;6:268-77.

24 Franklin CD, Smith CJ. Stereological analysis of histological parameters in experimental premalignant hamster cheek pouch epithelium. J Pathol 1980;130:201-15.

25 Eveson JW, MacDonald DG. Hamster tongue carcinogenesis. II Quantitative morphologic aspects of preneoplastic epithelium. J Oral Pathol 1981;10:332-41.

26 Eveson JW, MacDonald DG. Quantitative histological changes during early experimental carcinogenesis in the hamster cheek pouch. Br J Dermatol 1978;98:639-44.

27 Boysen M, Reith A. Stereological analysis of the nasal mucosa. III Stepwise alterations in cellular and subcellular components of pseudostratified, metaplastic and dysplastic epithelium in nickel workers. Virchows Arch (Cell pathol) 1982;40:311-25.

28 Boysen M, Reith A. Light and electron microscopic studies by manual and semiautomatic morphometric analysis of the basal cell layer. Objective discrimination of pseudostratified, metaplastic and dysplastic nasal epithelium. Methods Achiev Exp Pathol 1984;11:111-37.

29 Foraker AG, Reagan JW. Nuclear size and nuclear: cytoplasmic ratio in the delineation of atypical hyperplasia of the uterine cervix. Cancer 1956;9:470-9.

30 Klein-Szanto AJP, Nettesheim P, Topping DC, Olson AC. Quantitative analysis of disturbed cell maturation in dysplastic lesions of the respiratory tract epithelium. Carcinogenesis 1981:1:1007-16.

Requests for reprints to: Dr NG El-Labban, Institute of $\mathbb{8}$ Dental Surgery, Eastman Dental Hospital, 256 Gray's Inn Road, London WCIX 8LD, England. 